\title{
Diet and feeding behavior of the White-naped Jay, Cyanocorax cyanopogon (Wied, 1821) (Aves, Passeriformes, Corvidae) in a disturbed environment in central Brazil
}

\author{
Barros, RAM. ${ }^{a, b}$, Costa, CA. ${ }^{a}$ and Pascotto, MC. ${ }^{a *}$ \\ aLaboratório de Ornitologia, Instituto de Ciências Biológicas e da Saúde, Universidade Federal de Mato Grosso - UFMT, \\ Campus Universitário do Araguaia, Av. Sen. Valdon Varjão, 6390, Setor Drurys, \\ CEP 78600-000, Barra do Garças, MT, Brazil \\ bPrograma de Pós-Graduação em Imunologia e Parasitologia Básicas e Aplicadas, Universidade \\ Federal de Mato Grosso - UFMT, Campus Universitário do Araguaia. Av. Sen. Valdon Varjão, \\ 6390, Setor Drurys, 78600-000, Barra do Garças, MT, Brazil \\ *e-mail: mcpascot@hotmail.com
}

Received: June 4, 2013 - Accepted: July 30, 2013

\begin{abstract}
The White-naped Jay Cyanocorax cyanopogon (Wied, 1821) is an omnivorous and opportunistic species, with a multifarious diet. In view of the scarcity of available data in the literature, the aim was to investigate and describe the bird's diet, location of food items, foraging tactics, actual feeding behavior and intraspecific interactions, as a means of defining the items consumed. The study was carried out in a Cerrado area in the Araguaia Campus of the Federal University of Mato Grosso - UFMT, in Pontal do Araguaia, Mato Grosso State, Brazil, from August to December, 2006, and from April to October, 2010. All the feeding events were recorded through 136 hours of animal focal sampling, whereby it was shown that these birds predominantly consume animal nutrients, replenished by vegetable items and human food-waste. Arthropods were predominant in the diet, with ants as the most abundant and frequent item. The fruits, flowers and seeds of eleven plant species were also consumed. Food-waste, representing about $1 / 10$ of the total, was constantly consumed even when other food sources were available. Although active among the various strata, foraging is mainly on the ground. In the event of food-scarcity, the strategy employed is the hierarchical deployment of the members of various-sized groups, with the avoidance of direct competition. This versatility during all seasons, confirms total adaptation to the anthropic environment surrounded by native habitats that characterized the study site.
\end{abstract}

Keywords: anthropic environment, Cerrado, intraspecific interactions, food items, social organization.

\section{Dieta e comportamento alimentar de Cyanocorax cyanopogon (Wied, 1821) (Aves, Passeriformes, Corvidae) em um ambiente antropizado na região centro-oeste do Brasil}

\begin{abstract}
Resumo
Cyanocorax cyanopogon (Wied, 1821) é uma espécie onívora e oportunista, que se alimenta de diferentes itens alimentares. Como há poucos relatos na literatura sobre sua alimentação, este estudo visou descrever os itens alimentares consumidos, o local de captura do alimento, as táticas de forrageamento, o comportamento alimentar e as interações intraespecíficas de C. cyanopogon. O estudo foi realizado em uma área de Cerrado do Campus Universitário do Araguaia, Universidade Federal de Mato Grosso, em Pontal do Araguaia/MT, de agosto a dezembro de 2006 e de abril a outubro de 2010. Por meio da amostragem animal focal foram registrados todos os eventos alimentares, num total de $136 \mathrm{~h}$ de observações. Os resultados demonstraram que C. cyanopogon consome predominantemente alimentos de origem animal, seguidos pelos de origem vegetal e por resíduos alimentares. Os artrópodes foram predominantes em sua dieta e as formigas foram os itens animais mais abundantes e frequentes. Frutos, flores e sementes de onze espécies de plantas também foram consumidos. Resíduos alimentares representaram cerca de um décimo dos itens consumidos, sendo ingeridos mesmo em períodos de disponibilidade de outras fontes alimentares. C. cyanopogon é forrageadora ativa e utiliza diferentes estratos para a captura do alimento, com maior utilização do solo. Forrageia sempre em grupos de tamanhos variados e apresenta um sistema hierárquico para o consumo de itens menos abundantes, sem haver competição direta pelo alimento. Por consumirem diferentes tipos de alimentos e em todas as estações do ano, conclui-se que C. cyanopogon está totalmente adaptada ao ambiente ocupado pelo ser humano, mas circundado por vegetação nativa, característica do local de estudo.
\end{abstract}

Palavras-chave: ambiente antropizado, Cerrado, interações intraespecíficas, itens alimentares, organização social. 


\section{Introduction}

The Corvidae, a family of medium to large-sized Passeriformes species, is mainly composed of crows and jays, which occur worldwide, except at the poles. Although the genus Cyanocorax is mainly restricted to Central America, several species also occur in South America. In Brazil, all the eight species of jays belong to this same genus. Among these, Cyanocorax cyanopogon, popularly known as the White-naped Jay, is distributed from the northeast to the southeast of Para State, as well as throughout the states of Goias, Minas Gerais, Espirito Santo, Bahia and eastern Mato Grosso (Anjos, 2009).

Corvids are large-brained birds, whereby the capacity for developing various social strategies (Emery and Clayton, 2004), exploiting a wide variety of food resources (Goodwin, 1986), and burying food, even during times of abundance (De Kort et al., 2005). As omnivores, they feed on invertebrates, fruits, reptiles, amphibians, small birds and mammals, the eggs and chicks of other species, and carcasses (Sick, 1997). They present great variability in diet through spatial variation (Lefebvre et al., 1998), diversity in feeding strategies, the capacity to exploit each stratum, from the ground to the treetops (Sick, 1997), and a facility in using the beak and feet for food manipulation (Zusi, 1987).

Nonetheless, little is known about the diet and feeding behavior of jays in Brazil, the most studied species being the Blue Jay Cyanocorax caeruleus (Vieillot, 1818) (Anjos, 1991; Reinert and Bornschein, 1998), Plush-crested Jay Cyanocorax chrysops (Vieillot, 1818) (Uejima et al., 2012), and Curl-crested Jay Cyanocorax cristatellus (Temminck, 1823) (Amaral and Macedo, 2003). As to White-naped Jays, the few reports found in the literature were contributed by Sick (1997), Caten et al. (2007) and Anjos (2009).

Due to the scarcity of studies focusing on the diet and feeding behavior of jays, these two aspects, as well as the intraspecific interactions of the White-naped Jay in an anthropic Cerrado area in central Brazil, were investigated. Through dealing with an omnivorous and opportunistic species living in an anthropic environment, species consumption of a larger amount of manufactured items in times of natural food shortage could be expected.

\section{Material and Methods}

\subsection{Study area}

The study was carried out in the Araguaia Campus of the Federal University of Mato Grosso - UFMT (15 50 ' 43" S, 52 00 ' 33” W), in Pontal do Araguaia, Mato Grosso State, in the central-western region of Brazil, in an area of around 60 ha.

The predominant arboreal phytophysiognomy of the campus is Cerrado stricto sensu, with a few exotic species surrounding a built-up area, representing about $35 \%$ of the total, and comprised of physical spaces for teaching, research, sports activities and a canteen. The sampled area consisted of those areas surrounding the buildings, and the bordering native vegetation.

According to Köppen classification, the climate in the region is Aw, hot/humid, with two quite distinct seasons, one rainy (October to March) and the other dry (April to September). The average annual rainfall is $1,600 \mathrm{~mm}$, with average temperatures ranging from $22^{\circ} \mathrm{C}$ to $25^{\circ} \mathrm{C}$, and relative humidity of around $70 \%$, with the possibility of dropping to less than $30 \%$ in the dry season (FEMA, 2000). The average altitude is $350 \mathrm{~m}$.

\subsection{Sampling}

Sampling was carried out from August to December 2006 ( $n=10$ samples, 30 hours of observation), and from April to October 2010 ( $n=26,106$ hours), on nonconsecutive days, in the morning and evening, during the period from 07:00 to 18:00 h. On an average, each sampling took around three hours, thus reaching a total of 136 hours of observation.

White-naped jay feeding events were recorded through focal animal sampling (Altmann, 1974), with the aid of binoculars $\left(\mathrm{Nikn}^{\circledR} 7 \times 35\right)$. Once a group was found, it was tailed. On one of the birds starting to feed, the individual process was accompanied until the end, without any timelimit. In the event of simultaneous foraging by several, monitoring was entirely restricted to the activities of only one randomly chosen bird. Group-size was estimated by the maximum number of individuals observed together in a particular sampling set-up.

As in most cases C. cyanopogon does not eat large arthropods whole, the discarded parts (head and legs) were collected for identification to the lowest possible taxonomic level. Portions of the plants that had their fruits eaten were collected for further identification through the literature and/or by the curator of the Herbarium of the Araguaia Campus (UFMT). The classification of invertebrates followed the proposal of Brusca and Brusca (2007), and for plant species the taxonomy and classification system of APG III (Haston et al., 2009).

The White-naped Jay was considered a potential seed disperser through the whole ingestion of seeds, fruits or diaspores (seed-plus-aril), without crushing or pecking (Schupp, 1993).

As regards feeding behavior, the following records were taken: i) of search, through passive or active foraging; ii) attack, either by gleaning, to so capture prey from a nearby substrate, including the ground, or by lunging, when the food item is beyond reach during rapid terrestrial movement, as an alternative to flight for pursuit and capture; iii) food-handling techniques, viz.: pecking - pecking fruits too large to swallow whole; clasping - holding food items with the feet; gulping - swallowing upon catching, without manipulation other than briefly holding in the bill; tearing - evisceration or dissection of food items into smaller pieces; and iv) foraging sites (air, ground, live foliage, and ant and termite nests). All feeding behavior was according to Remsen Junior and Robinson (1990). Furthermore, recordings were also made of the number of 
individuals foraging, the presence or absence of sentinels, and the intraspecific interactions during feeding.

Occurrence frequency of food items in the diet was calculated by dividing the number of samplings in which a particular item was consumed, by the total number of samplings within each period (2006 and 2010). Expression was by percentage. Furthermore, in the case of repeated ant-nest foraging, only the number of ants ingested by a single individual was taken into account. This method was adopted for all the other items.

\section{Results}

\subsection{Diet}

The jay's diet was variable, with a predominance of animal items (59\%), and sequentially, vegetable food-stuff $(28 \%)$ and food-waste (13\%). The proportions were alike in the two sampling periods.

The animal food mainly consisted of arthropods belonging to the subphyla Cheliceriformes (Arachnida) and Hexapoda (Insecta), although earthworms (Filo Annelida) were also consumed (Table 1). Insects comprised the largest source of animal proteins $(87 \%)$, the remainder consisting of spiders and earthworms.

Among the insects, ants were the most frequent diet item, and spiders the second most among the arthropods, as a whole. When unidentifiable through direct observation, insect larvae and those of other arthropods were included in a separate category (Table 1).

Although ants were the most frequent item in the diet, termites were the most abundant in almost all the samples, with consumption peaks in December, 2006, and late April-May and August, 2010. On the other hand, butterflies were consumed in only small amounts, and even so, only in 2010, while the ingestion of a single bee was noted only in November, 2006.

Unsuccessful attacks on the nests of Rufous Hornero Furnarius rufus (Gmelin, 1788), the Great Kiskadee Pitangus sulphuratus (Linnaeus, 1766), Guira Cuckoo Guira guira (Gmelin, 1788), and Pale-breasted Thrush Turdus leucomelas Vieillot, 1818 were observed during both sampling periods, all with vigorous repulsion.

The fruits, flowers, and seeds of 11 plant species, belonging to ten families, were consumed, with Anacardiaceae as the most (Table 2). Out of these, five species constituted a stable item during both sampling periods.

The highest proportion of fruits consumed was attributed to Jambul Syzygium cumini (L.) Skeels in 2006 and Inga Inga laurina (SW.) Willd in 2010 (Table 2). Together, these two species comprised roughly $50 \%$ of all the vegetable items consumed in 2010. Although in 2006, Jambul accounted for more than half of the vegetable diet in November and December, in 2010 its consumption from June to October was only moderate.

Jambul and Inga were the most frequent ingredients in both sampling periods (Table 2). Cashew Anacardium occidentale (L.) was consumed in August and September, its fruiting season in the region, and Mango Mangifera indica $\mathrm{L}$. in September and October. Only one feeding event with Eriotheca gracilipes (K. Schum.), White Sucupira Pterodon emarginatus Vogel., and Vochysia haenkeana (Spreng.) Mart. was observed.

Table 1. Invertebrates consumed by White-naped Jay and its frequency of occurrence in the diet. $n=$ number of items consumed. The number of samples was 10 in 2006 and 26 in 2010.

\begin{tabular}{|c|c|c|c|c|}
\hline \multirow{2}{*}{ Food items (Taxa and common names) } & \multicolumn{2}{|c|}{$\mathrm{n}$} & \multicolumn{2}{|c|}{ Frequency of occurrence (\%) } \\
\hline & 2006 & 2010 & 2006 & 2010 \\
\hline \multicolumn{5}{|l|}{ Arthropoda } \\
\hline \multicolumn{5}{|l|}{ Hexapoda, Insecta } \\
\hline \multicolumn{5}{|l|}{ Orthoptera } \\
\hline Acrididae (grasshoppers) & 7 & 3 & 60 & 12 \\
\hline Gryllidae (crickets) & 8 & 7 & 70 & 23 \\
\hline \multicolumn{5}{|l|}{ Isoptera } \\
\hline Termitidae (termites) & 7 & 42 & 30 & 46 \\
\hline \multicolumn{5}{|l|}{ Hymenoptera } \\
\hline Formicidae (ants) & 9 & 59 & 70 & 73 \\
\hline Apidae (bees) & 1 & & 10 & \\
\hline \multicolumn{5}{|l|}{ Lepidoptera } \\
\hline Rhophalocera (butterflies) & & 13 & & 42 \\
\hline \multicolumn{5}{|l|}{ Hemiptera } \\
\hline Cicadellidae (cicadas) & & 20 & & 15 \\
\hline \multicolumn{5}{|l|}{ Cheliceriformes } \\
\hline \multicolumn{5}{|l|}{ Arachnida } \\
\hline Araneae (spiders) & 12 & 21 & 70 & 58 \\
\hline \multicolumn{5}{|l|}{ Annelida } \\
\hline Oligochaeta (earthworms) & & 3 & & 12 \\
\hline Other unidentified items & 4 & 13 & 30 & 38 \\
\hline
\end{tabular}


Table 2. Vegetal items present in the diet of White-naped Jays in a disturbed environment of Cerrado, Pontal do Araguaia, Mato Grosso State, center-west Brazil. The number of samples was 10 in 2006 and 26 in 2010.

\begin{tabular}{|c|c|c|c|}
\hline \multirow{2}{*}{ Family/Species } & \multirow{2}{*}{ Portion consumed } & \multicolumn{2}{|c|}{ Frequency of occurrence $(\%)$} \\
\hline & & 2006 & 2010 \\
\hline \multicolumn{4}{|l|}{ Anacardiaceae } \\
\hline Anacardium occidentale* & pulp & 40 & 19 \\
\hline Mangifera indica* & pulp & 20 & 19 \\
\hline \multicolumn{4}{|l|}{ Annonaceae } \\
\hline Annona coriacea & flower & & 8 \\
\hline \multicolumn{4}{|l|}{ Arecaceae } \\
\hline Orbignya speciosa & pulp & & 27 \\
\hline \multicolumn{4}{|l|}{ Caesalpiniaceae } \\
\hline Copaiffera langsdorfii & seed & & 8 \\
\hline \multicolumn{4}{|l|}{ Fabaceae } \\
\hline Pterodon emarginatus & seed & & 4 \\
\hline \multicolumn{4}{|l|}{ Malvaceae } \\
\hline Erioteca gracilipes & seed & 10 & \\
\hline \multicolumn{4}{|l|}{ Mimosoideae } \\
\hline Inga laurina* & seed & 10 & 27 \\
\hline \multicolumn{4}{|l|}{ Moraceae } \\
\hline Brosimum gaudichaudii & fruit & 20 & 8 \\
\hline \multicolumn{4}{|l|}{ Myrtaceae } \\
\hline Eugenia jambolana* & pulp & 40 & 31 \\
\hline \multicolumn{4}{|l|}{ Vochysiaceae } \\
\hline Vochysia haenckeana & seed & 10 & \\
\hline
\end{tabular}

*exotic species.

In plants, consumption was mostly restricted to seeds $(46 \%)$ and fruit pulp (36\%), although whole fruits and flowers ( $9 \%$ each) were occasionally included (Table 2).

Among fruit items, $60 \%$ were fleshy and $40 \%$ dry. Whereas the seeds and fruits of Copaifera langsdorffii Desf., Inga and Brosimum gaudichaudii Trecul were swallowed whole and without crushing, in other species seeds were ruptured.

Food-waste, representing about $1 / 10$ of all the items consumed, constituted a significant element. Obtainment was both on the ground and among canteen left-overs.

Consumption consisted of bread crumbs, the remains of cake and snack food, rice, papaya peel, apples, bananas, maize and eggshells, with bread crumbs as the most frequent. The birds also rummaged among the plastic packaging of ketchup, mustard and mayonnaise, as well as paper napkins, all directly abstracted from waste-bins. Although the plastic containers and napkins themselves were not consumed, these were manipulated in the search for food waste.

\subsection{Feeding behavior}

Active foraging is employed by White-naped Jays, when searching for food. One form is rummaging on the ground, under leaves or pieces of tree bark, and amidst grass. The other, gleaning, is the most usual attack behavior, whence, an often used tactic is the higher placed bird pouncing upon prospective ground-level prey.
The most employed techniques for dealing with food items included pecking, clasping, and tearing. Fleshy and large fruits in particular were disintegrated by pecking. After catching food, regardless of it being animal, vegetable, or food-waste, the bird always flew to a nearby tree branch. On landing, and while still holding the item with one foot, more often the left, it would begin to remove small pieces and portions with the beak. Larvae, spiders, and earthworms were swallowed, either whole or after being torn apart.

Mainly due to the availability of insects and large fruits, foraging was mostly on the ground (51.1\%). Arthropods, such as spiders and insects, were caught, and fruits collected amidst foliage. Exceptionally, ants and termites were, in most cases, captured and eaten at the nests. On the other hand, airbourne insects, such as butterflies, were caught on the wing.

Regarding cobwebs suspended from leaves, jays were often observed to cut the leaves at the petiole, to so release the web. On falling, the bird would immediately fly down, grasp the web with its toes and begin pecking, to so remove and simultaneously dismember the spider, prior to eating.

Large and fleshy fruits, such as Mango and Cashew, were consumed, both on the ground, or when still attached to the branch. On the other hand, smaller fruits, such as Jambul, Inga, and White Sucupira, were often pried off with the beak and taken to a nearby branch, prior to ingestion. In the case of pods, such as those of Inga, the husk was 
first removed by pecking. Holding the fruit by the edges, only diaspores were prized out for ingestion.

White-naped Jays feed in various-sized groups. In the study area, the maximum size of foraging groups was estimated, in 2006, at 9 individuals, and in 2010, at 14. They were most often observed foraging in subgroups of 3 to 5 members; a lone-feeding jay was a rare sight.

A group hierarchical system often prevailed, when feeding on less abundant resources. On encountering food, this system was spontaneously established within the group. Apparently this appears to be the usual foraging pattern of the White-naped Jay.

This group hierarchical system of feeding in $C$. cyanopogon starts with an individual collecting a food item, and then flying to a tree in order to begin consumption. Several other birds approach that which is feeding and remain perched nearby, simply observing.

On finishing feeding, the first individual flies away, whereupon there is a subsequent rotation of positions, with an upward shift of hierarchical levels: in other words number 2 , now number 1 , flies to the food and begins feeding. This shift is repeated until total consumption of the food item. In the event of a new arrival, with the intention of entering the system, this always takes up a position the furthest away from individual 1, thus assuming the last position in the hierarchy.

On an average, each individual remains three minutes foraging, while the remainder passively wait without vocalizing. Only once, when an individual took about six minutes, did the next individual become restless and begin to insistently vocalize. Even so, at no time did any of the individuals become aggressive or try to steal the food: hierarchy was respected, each awaiting their turn.

Another form of group-foraging was often observed at the campus canteen, where several birds would keep watch in the branches over occupied tables. Vocalization was frequent. On perceiving discarded food-stuff, one would quickly fly to the ground, pick it up, and then fly to a remote spot for consumption, in this followed by all the other group members. Worthy of note, jays are intractable, and do not become tame. They do not come close to humans, but always remain on the alert, simply awaiting an opportunity to pick up food.

\section{Discussion}

\subsection{Diet}

Through exploiting an appreciable variety of protein sources, and resorting, on a whole, to annual foraging cycles that coincide with local periods of greater availability of food resources, thus implying a year-long variation in diet, the White-naped Jay can be considered as an omnivorous and opportunistic species. This also applies to the Azure Jay (Anjos, 1991), the Plush-crested Jay (Uejima et al., 2012), the Florida Scrub Jay Aphelocoma coerulescens (Bosc, 1795) (Morgan et al., 2010), and the Curl-crested Jay (Amaral and Macedo, 2003), thereby demonstrating that the various jay species appear to exploit the resources available at the various times of the year and in the different regions, in a similar and effective manner.

Although omnivorous, animal food was found to make up the largest part of the White-naped Jay diet. This was found to be so with Azure (Anjos, 1991), Curlcrested (Amaral and Macedo, 2003) and Plush-crested (Uejima et al., 2012) jays. Nonetheless, in a study involving the same population of jays, but over a different period, the consumption of insects and fruits was found to be in similar proportions (Caten et al., 2007).

Invertebrates were the only source of animal food in the diet of the White-naped Jay. Arthropods also seem to be the invertebrates most consumed by corvids (Anjos, 1991; Reinert and Bornschein, 1998; Amaral and Macedo, 2003; Langen and Vehrencamp, 1998; Morgan et al., 2010; Nocedal, 2010; Uejima et al., 2012). Although no vertebrate species have been recorded as actually being consumed by White-naped jays, the attempts to attack bird nests, as observed in the present study, is ample evidence of this predatory behavior being typical in jays, although only opportunistically.

According to the present data, the frequent inclusion of ants in the White-naped Jay diet presupposes this to be a major source of animal protein, as placed in evidence by their high occurrence frequency in the diet in both sampling periods.

Fruit consumption in White-naped Jays was moderate, and often over a short time-span, as a consequence of the short-term fruiting periods of some plant species. On the other hand, the occurrence of arthropods in the diet is apparently more regular, with consumption extending from June to December, when, incidentally, most plant species reached fruiting-peaks ("pers. obs."). This was corroborated by the high occurrence-frequency of most arthropod species in the diet, with some groups reaching $50 \%$ or over. On the other hand, only few vegetable items presented high values, these not exceeding $40 \%$.

Several exotic plant-species, surrounding the built-up area of the campus, can be included among resources. These abundant species provided extra food for the local jay population, especially during the dry season, when fruiting species are scarce in the Cerrado (Oliveira, 2008). According to Argel-de-Oliveira (1998), fruit consumption by opportunistic frugivorous birds, as a source of hydration, tends to increase in times of water scarcity. This also appears to be true for the White-naped Jay, with the ingestion of larger amounts of fleshy fruits at the end of the dry season. Moreover, most of the fruits consumed were exotic species. Besides furnishing the local jay population with resources, these exotic plants also constitute a foraging site for other items, such as spiders that weave their webs on the leaves of various plant species, termites that live in nests in tree-canopies, and ants taken directly from anthills under trees. Thus, many of the feeding activities of jays could be associated to built-up areas and the surrounding exotic plants.

While White-naped Jays often consume fruits, this is restricted to the pulp and, only occasionally, seeds. 
Thus, contrary to the Curl-crested Jay, which is regarded as a potential seed disperser in the Cerrado (Amaral and Macedo, 2003), the White-naped cannot be regarded as a seed disperser for most vegetable species. Although Uejima et al. (2012) recorded Plush-crested Jays as eating the fruits of 24 plant species, with the exception of Araucaria angustifolia (Bertol.) Kuntze, they did not mention its potential for seed dispersal.

Since, in the case of other jay-species, most studies have been carried out in non-disturbed areas, the consumption of food-waste is notably absent from the literature. One exception was a study by Uejima et al. (2012), who also recorded consumption of many kinds of foodstuffs discarded by humans, such as garbage, bread, meat, cookies, grain plants and maize, similar to that found in this study for the White-naped Jay. Generally, areas with a certain degree of human occupation provide additional food resources, in the form of exotic fruits and food-waste.

Based on these data, it can be inferred that jays exploit the surrounding environment to the maximum, even to the point of supplementing their diet with man-made food-stuff. However, in White-naped Jays, this behavior is habitual, regardless of local natural-food presence, and thus contrary to the hypothesis of their consuming more artificial food in times of scarcity of the natural. Our data support the hypothesis proposed by Goulart et al. (2011), whereby, according to their nutritional needs, urban areas and agroforestry systems provide bird communities with a wide and additional variety of food resources. Thus, we may infer that the White-naped Jay is well-adapted to the study site, by finding food throughout the year, whether animal, vegetable or artificial.

Although it is usual to find reports in the literature, citing jays as preying on eggs and chicks, neither in this study, nor in that of Caten et al. (2007), was this actually observed. However, the observation of bird species pursuing White-naped Jay individuals presupposes this possibility.

\subsection{Feeding behavior}

The White-naped Jay is an active foraging species, more so than the Azure, through exploring a larger spatial area in a shorter period of time, when on the search (Anjos, 1991). This strategy is used by birds and mammals (Chapman et al., 1989), to so increase the encounter-rate of prey in sites where this is abundant, thereby minimizing movement (Zoroa et al., 2011). This was apparently the case of the White-naped Jay in the study site. Besides exploiting the entire space within the built-up area of the campus, the birds also moved to an adjacent area with native vegetation, in the search for fresh-food resources.

The presumption, that birds occupying the same environment together with human beings preferably forage on the ground (Beissinger and Osborne, 1982), was found to apply to the White-naped Jay. As with Plush-crested Jays (Uejima et al., 2012), the White-naped preferably gleans. This strategy requires lower energy expenditure, when compared to other foraging tactics (Remsen Junior, 1985).
Variation in the number of individuals in each subgroup may be related to an ideal group size, in accordance with the availability and distribution of resources in the surrounding environment. A similar procedure has been observed in other jay species, such as the Curl-crested Jay, wherein groups consisted of 4 to 16 (Nocedal, 2010) or 9 to 11 (Amaral and Macedo, 2003) individuals. In the Azure Jay, individuals come together in subgroups, when exploiting food sources with clustered spatial distribution, but congregate, when foraging randomly distributed animal items (Anjos, 1991). This was also the case with the White-naped Jay.

Disturbance by human activities is a risk factor in predation (Frid and Dill, 2002). When searching for the available food, White-naped Jays are apparently capable of exploiting anthropic environments, even in the presence of humans. Even so, these activities were always undertaken in groups, never individually, thereby clearly indicating the prevailing intraspecific social interactions during foraging.

Associated to their intelligence and high brain development, corvids are known for innovative behavior (Emery and Clayton, 2004), thereby manifesting farreaching social organization (Anjos, 2009). Animals that live in groups require special strategies, as a means of sharing the same resources, since intraspecific conflicts are capable of rupturing stability and hindering cooperation between individuals (Chiarati et al., 2010). In this study, a well-coordinated hierarchy between White-naped Jay individuals was observed during foraging, with the mutual sharing of food resources, and no direct competition. However, this strategy has not been reported among other congeneric species, not even by Morgan et al. (2010), when studying the Florida Scrub Jay. Through the absence of sexual dimorphism in the plumage coloration of Whitenaped Jays, at the moment it was impossible to ascertain whether the hierarchy manifest during foraging could be associated to dominance, age, gender, degree of kinship, or affinity between individuals. Further studies with marked and sexed individuals are called for to test which factors exert an influence on hierarchy during White-naped Jay foraging.

Based on White-naped Jay plasticity when exploiting food resources, whether animal, vegetable, or artificial, as well as the increase in the number of individuals foraging together from one sampling period to the other, and the manifest hierarchical system prevalent during feeding events, it may be concluded that this species has become adapted to the anthropic environment it lives in, and is practically inure to environmental changes. Finally, as long as it is surrounded by native vegetation, it can be presumed that the generalist feeding habits of the White-naped Jay facilitate its survival in environments changed by humans.

\section{Acknowledgments}

M. C. Pascotto wishes to thank FAPEMAT for sponsoring the projects which made this work possible (Processes $873 / 2006$ and 738702/2008), as well as the curator (M. S. 
Lacerda) of the Herbarium of the Campus Universitário do Araguaia, Universidade Federal de Mato Grosso, for identification of some plant species, and anonymous reviewers.

\section{References}

ALTMANN, J., 1974. Observational study of behavior: sampling methods. Behaviour, vol. 49, no. 3, p. 227-267. http://dx.doi. org/10.1163/156853974X00534. PMid:4597405

AMARAL, MF. and MACEDO, RHF., 2003. Breeding patterns and habitat use in the endemic Curl-crested Jay of central Brazil. Journal of Field Ornithology, vol. 74, no. 4, p. 331-340. http:// dx.doi.org/10.1648/0273-8570-74.4.331.

ANJOS, L., 1991. O ciclo anual de Cyanocorax caeruleus em floresta de Araucária (Passeriformes: Corvidae). Ararajuba, vol. 2, p. 19-23.

ANJOS,L., 2009. Family Corvidae (crows). In DEL HOYO, J., ELLIOTT, A. and CHRISTIE, DA. (Eds.). Handbook of the birds of the world. Barcelona: Lynx Edicions. p. 494-640.

ARGEL-DE-OLIVEIRA, MM., 1998. Aves que plantam: frugivoria e dispersão de sementes por aves. Boletim do Centro de Estudos Ornitológicos, vol. 13, p. 1-71.

BEISSINGER, SR. and OSBORNE, DR., 1982. Effects of urbanization on avian community organization. The Condor, vol. 84, no. 1, p. 75-83. http://dx.doi.org/10.2307/1367825.

BRUSCA, RC. and BRUSCA, GJ., 2007. Invertebrados. 2nd ed. Rio de Janeiro: Guanabara Koogan. 968 p.

CATEN, HT., OLIVEIRA, JPF. and PASCOTTO, MC., 2007. Alimentação de Cyanocorax cyanopogon (Corvidae, Passeriformes, Aves) em uma área de Cerrado na região leste de Mato Grosso. In Anais do VIII Congresso de Ecologia do Brasil, 2007, Caxambu. Caxambu: Sociedade de Ecologia do Brasil. p. 1.

CHAPMAN, CA., CHAPMAN, LJ. and MCLAUGHLIN, RL., 1989. Multiple central place foraging by spider monkeys: travel consequences of using many sleeping sites.Oecologia, vol. 79, no. 4, p. 506-511. http://dx.doi.org/10.1007/BF00378668.

CHIARATI, E., CANESTRARI, D., VERA, R., MARCOS, JM. and BAGLIONE, V., 2010. Linear and stable dominance hierarchies in cooperative carrion crows. Ethology, vol. 116, no. 4, p. 346-356. http://dx.doi.org/10.1111/j.1439-0310.2010.01741.x.

DE KORT, SR., DICKINSON, A. and CLAYTON, NS., 2005. Retrospective cognition by food-caching western scrub-jays. Learning and Motivation, vol. 36, no. 2, p. 159-176. http://dx.doi. org/10.1016/j.lmot.2005.02.008.

EMERY, NJ. and CLAYTON, NS., 2004. The mentality of crows: convergent evolution of intelligence in corvids and apes.Science, vol. 306, no. 5703, p. 1903-1907. http://dx.doi.org/10.1126/ science.1098410. PMid:15591194

FRID, A. and DILL, L., 2002. Human-caused disturbance stimuli as a form of predation risk. Conservation Ecology, vol. 6, no. 1, p. 11-26.

Fundação Estadual do Meio Ambiente - FEMA, 2000. Diagnóstico ambiental do Parque Estadual da Serra Azul. Barra do Garças.
GOODWIN, D., 1986. Crows of the World. London: British Museum (Natural History) Press.

GOULART, FF., VANDERMEER, J., PERFECTO, I. and MATTA-MACHADO, RP., 2011. Frugivory by five bird species in agroforest home gardens of Pontal do Paranapanema, Brazil. Agroforestry Systems, vol. 82, no. 3, p. 239-246. http://dx.doi. org/10.1007/s10457-011-9398-z.

HASTON, E., RICHARDSON, JE., STEVENS, PF., CHASE, MW. and HARRIS, DJ., 2009. The Linear Angiosperm Phylogeny Group (LAPG) III: a linear sequence of the families in APG III. Botanical Journal of the Linnean Society, vol. 161, no. 2, p. 128-131. http://dx.doi.org/10.1111/j.1095-8339.2009.01000.x.

LANGEN, TA. and VEHRENCAMP, SL., 1998. Ecological factors affecting group and territory size in White-throated Magpie-jays. The Auk, vol. 115, no. 2, p. 327-339. http://dx.doi. org/10.2307/4089191.

LEFEBVRE, L., GAXIOLA, A., DAWSON, S., TIMMERMANS, S., ROSZA, L. and KABAI, P., 1998. Feeding innovations and forebrain size in Australasian birds. Behaviour, vol. 135, no. 8, p. 1077-1097. http://dx.doi.org/10.1163/156853998792913492.

MORGAN, GM., BOUGHTON, RK., RENSEL, MA. and SCHOECH, SJ., 2010. Road effects on food availability and energetic intake in Florida Scrub-jays (Aphelocoma coerulescens). The Auk, vol. 127, no. 3, p. 581-589. http://dx.doi.org/10.1525/ auk.2010.09033.

NOCEDAL, J., 2010. Cyanocorax dickeyi: una especie endémica del ocidente mexicano, conocida localmente como la urraca pinta. El Canto del Centzontle, vol. 1, no. 2, p. 123-133.

OLIVEIRA, PEAM., 2008. Fenologia e biologia reprodutiva das espécies de Cerrado. In SANO, SM., ALMEIDA, SP. and RIBEIRO, JF. (Eds.). Cerrado: ecologia e flora. Brasília: Embrapa Cerrados. p. 273-290. vol. 1.

REINERT, LB. and BORNSCHEIN, RM., 1998. Alimentação da gralha-azul (Cyanocorax caeruleus, Corvidae). Ornitologia Neotropical, vol. 9, p. 213-217.

REMSEN JUNIOR, JV., 1985. Community organization and ecology of birds of high elevation humid forest of the Bolivian Andes. Ornithological Monographs, vol. 36, no. 36, p. 733-756. http://dx.doi.org/10.2307/40168314.

REMSEN JUNIOR, JV. and ROBINSON, SK., 1990. A classification scheme for foraging behavior of birds in terrestrial habitats. Studies in Avian Biology, vol. 13, p. 144-160.

SCHUPP, EW., 1993. Quantity, quality and the effectiveness of seed dispersal by animals. Vegetatio, vol. 107/108, p. 15-29.

SICK, H., 1997. Ornitologia brasileira. Rio de Janeiro: Nova Fronteira. $912 \mathrm{p}$.

UEJIMA, AMK., BOESING, AL. and ANJOS, L., 2012. Breeding and foraging variation of the Plush-crested Jay (Cyanocorax chrysops) in the brazilian Atlantic Forest. The Wilson Journal of Ornithology, vol. 124, no. 1, p. 87-95. http://dx.doi.org/10.1676/11-027.1.

ZOROA, N., FERNANDÉZ-SÁEZ, MJ. and ZOROA, P., 2011. A foraging problem: sit-and-wait versus active predation. European Journal of Operational Research, vol. 208, no. 2, p. 131-141. http://dx.doi.org/10.1016/j.ejor.2010.08.001.

ZUSI, RL., 1987. A feeding adaptation of the jaw articulation in the New World jays (Corvidae). The Auk, vol. 104, no. 4, p. 665-680. 